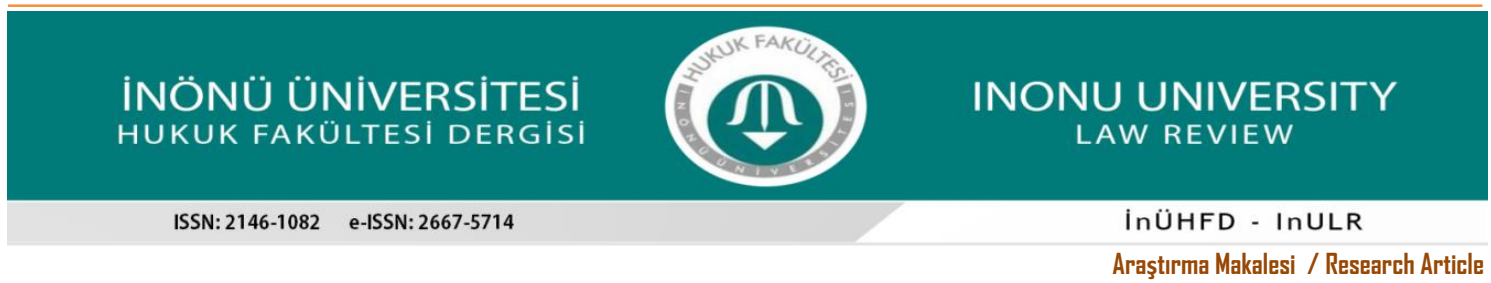

\title{
LEGAL STATUS OF WORKERS WORKING IN THE BORDER ZONES OF NEIGHBORING COUNTRIES
}

\author{
KOMŞU ÜLKELERIN SINIR BÖLGELERINDE ÇALIŞAN IŞÇILLERIN HUKUKİ STATÜSÜ
}

\author{
M. Halit KORKUSUZ* $*$ (D)
}

Makale Bilgi

Gönderi: 11/07/2021

Kabul : 09/12/2021

\section{Anahtar Kelimeler}

Sinır İşçilerinin

Standartlarl,

Sinır Ticaretinin

Katklsl,

Eşit Davranma Borcu,

Ayrımcılık Yasağı.

\section{Article Info}

Received: 11/07/2021

Accepted: 09/12/2021

\section{Keywords}

\section{Border Workers}

Standarts,

The Contribution of

Border Trade,

Obligation of Equal

Treatment,

Prohibition of

Discrimination.
Özet

https://dai.org/l1.21492/inuhfd.969771 doi

Dünyada son zamanlarda sınır bölgelerinde ya da sınırın diğer tarafında yaşama veya ekonomik olarak daha gelişmiş komşu ülkelerde çalışma eğilimi artmaya devam etmektedir. Dünyada sınır ticaretinin artması sonucunda hem sınırlı ekonomiye sahip ülkelerin işçileri, hem de daha gelişmiş sınır ülkelerinin vatandaşları için ek istihdam imkanlarının olduğu tartışma dışıdır. $\mathrm{Bu}$ durum ekonomik olarak daha gelişmiş olan sınırdaş ülkeler için artmaya devam etmektedir. Nitekim sınır bölgelerinde bulunan işyerlerinin de daha dezavantajlı komşu ülkelerden gelen ve ekonomik imkânları daha sınırlı olan ülkelerin çalışanlarına katkı sağlaması çok önemlidir. Ancak bu çalışanların çalışmakta oldukları ülkenin vatandaşı olmadıkları için uygulamada çeşitli mağduriyetlerle karşılaşmakta oldukları bir gerçektir. Öte yandan dünyada sınır ticaretindeki yükselişin bir sonucu olarak, özellikle daha gelişmiş ülkelerin vatandaşları için ilave istihdam imkanları olduğu da tartışılmaz bir gerçektir. İstihdam sağlamak için önemli bir imkan olan sınır ticaretinin çok sayıda insanın malların nakliyesi, otel, restoran, depolama merkezi gibi işletmelerin işletilmesi gibi alanlarda iş bulmasını sağladığı açıktır. Komşu ülkede geçici süreyle de olsa çalışma hakkı bulunan yabancı işçiler bakımından; işverenler "eşit muamele yükümlülüğ̈̈" ve "ayrımcılık yasağı" ve diğer ILO standartlarına uymak zorundadır. Aksi durum, son yüzyılda elde edilen ve uluslararası sözleşmelerle sağlanan haklara zarar verebilecektir.

\begin{abstract}
In the world, recently, the tendency to live in border regions, on the other side of the border and work in more economically developed neighbouring countries continues to increase. On the other hand, as a result of the increase in the border trade in the world, it is indisputable that there are additional employment opportunities, especially for the citizens of more developed countries. This situation for economically more developed neighbouring countries continues to increase. It is a fact that these workers suffer in practice because they are not citizens of the country they are working in. On the other hand, as a result of the increase in the border trade in the world, it is indisputable that there are additional employment opportunities, especially for the citizens of more developed countries. It is clear that border trade, which is a good advantage in providing employment, leads to employment of a large number of people due to the transportation of goods, or to run the businesses of hotels, restaurants, storage centres and customs establishments. Among the workers who have the right to work in the neighbouring country, even temporarily, on the grounds of foreignness; employers must comply with the "obligation of equal treatment" and "prohibition of discrimination" and other ILO standards. Otherwise, it may harm the universal gains of the employees achieved in the last century and provided by international agreements.
\end{abstract}




\section{INTRODUCTION TO BORDER ZONES WORKS}

Throughout history, humanity has seen trade as one of its main sources of livelihood. Trade -in the form of exchange of goods- is first developed between neighbouring tribes and cities, as in the form of border trade. In the XIX ${ }^{\text {th }}$ century, the volume of international trade increased exponentially and increased even more after the Second World War. These two booms in international trade volume are associated with the age of exploration and trade liberalization, respectively. However, the increase in the volume of international trade has not led to a directly proportional increase in border trade. In contrast, the relative importance of overseas trade seems to have exceeded border trade's relative importance. On the other hand, in the $\mathrm{XX}^{\text {th }}$ century, we must say that border trade has been developed all over the world, and border trade has come to a level that benefits both sides of borders.

Access to international markets is crucial to economic development. In today's world, many different efforts are put forward to increase trade. In other words, increasing the market share as well as reducing the commercial transaction costs has gained importance. For small traders, logistics and freight costs, customs administrative issues and border costs have become more works than before. While the importance of small and medium-sized enterprises (SMEs) in the overall economy is widely acknowledged, until recently those enterprises were largely absent from trade facilities.

In the development of trade, World War II was an important milestone. Subsequent trade agreements, combined with tremendous advances in transport and communication technology, have resulted in unprecedented growth in international trade. For example, between 1996 and 2013, global trade in goods grew at an average annual rate of $7.6 \%{ }^{1}$.

Undoubtedly, with the development of trade between neighbouring countries, it is a fact to argue that workers, who are more economically weak, prefer neighbouring countries with more job opportunities and more economic opportunities.

\section{EMPLOYMENT OPPORTUNITIES IN BORDERING COUNTRIES}

\section{A. Benefits of Trading and Investing in the Border Areas of Neighbouring Countries} as follows:

It is possible to determine for the investments and commercial targets in the border regions

1- Increasing investments and production for the export industrial goods,

2- By bringing new dimensions to international trade: It is related to foreign trade and investments. With the removal or reduction of bureaucracy, imports are cheap and easy realization,

3- With the increase in investment and production, new job opportunities increase employment,

4- With the technology and knowledge transfer brought by foreign capital, the host country contributing to the development of workforce qualifications and production technology,

5- Increasing foreign exchange inflow to the host country by developing foreign trade,

6- More than banking and financing opportunities in international trade use,

7- Contributing to the competitiveness of domestic producers in international markets,

8- Reexport (re-export) and the advantages of transit trade transactions: It has many purposes, such as the use of facilities. Undoubtedly, in addition to the abovementioned advantages regarding all private trade areas (including free trade zones), it is possible to say that doing business in border countries has the following advantages:

- Freely determined commercial activity according to the market needs and conditions of the neighbouring country opportunity,

- Access to all domestic and foreign markets,

- Reduced bureaucratic procedure and dynamic business management,

- Strategic advantage,

- Possibility of affordable infrastructure for all kinds of commercial and industrial activities,

- Ease of benefiting from supply chain opportunities,

- Trade facility opportunity

\footnotetext{
${ }^{1}$ FERRO, Cécile et al.: "Trading Across Borders: A New Approach to Measuring Trade Processes Across Borders", https://www.doingbusiness.org/content/dam/doingBusiness/media/Annual-Reports/English/DB16-Chapters/DB16-CSTAB.pdf, (Date of Access: 05.05.2021), p.6.
} 
- Opportunity to benefit from the labour force of the neighbouring country, which has a more limited capacity, especially economically ${ }^{2}$.

\section{B. Contribution of Border Trade to Employment}

One of the important effects of border trade is its contribution to employment. Even adopting simple (but often still costly) proposals such as automating trade and customs processes can reduce costs for these income groups by $2.8-3.6 \%^{3}$. A study finds that introducing new technologies, such as an electronic single window, that limit the number of interactions between firms and border agencies is associated with both an increase in the number of firms and the volume of exports of user firms. In measuring the time and cost associated with border and documentary compliance across 190 economies, OECD supports more efficient regulatory practices for trading across borders ${ }^{4}$.

The contribution of border trade to the economy is that border trade meets the needs of people living in border provinces in a cheaper and easier way. The most important contribution of border trade to the economy is its contribution to the employment. In this way, the welfare level of the people increases in the regions where border trade is carried out, contributing to the development of the entrepreneurial spirit of the local people. Furthermore, due to the lack of bureaucratic delays, it also contributes to the development of the country's foreign trade volume. One of the advantages of border trade is that products, especially products that cannot be produced in one border country, can easily be brought from the other border countries and bottlenecks can be overcome.

There is a large mass of people in the border trade that lives by transportation. The earnings of this segment are constantly falling due to the competition they face and their distance to the major cities that are the centre of employment.

In general, the socio-economic status of the provinces where border trade is carried out is low. A significant part of the people living in these provinces work in the primary sector and earn their living from this sector. In particular, the frequent visits of citizens of the two border countries to the neighbouring border regions make a very important contribution to the economies of traders (hotel, restaurant, cafe owners and wholesale shoppers), and to the creation of new employment opportunities -especially in the form of SMEs. On the other hand, where the exchange rate and volume is high, large-scale businesses may be started. Bigger enterprises offer more employment opportunities for the citizens of both border States.

In order for the border trade to induce employment on both sides of the border, it is very important that there is no discrimination against the citizens of the other border State. In this regard, there are many principles that the International Labour Organization (ILO) has adopted.

\section{Labour Migration Between Border Countries}

In practice, agreements can be made between bordering countries and regarding border regions, for the Exchange of goods or short-term visits. If there is such an agreement, the citizens of the two sides residing in the border regions can enter and leave the designated border regions of the other country and can also Exchange goods, provided that it does not exceed a certain amount.

If bordering countries; if they have a special agreement on the free passage of goods and services; In this case, the rules for both the passage of goods and the passage of workers are determined. Both parties know the rules and know how to act. In practice, agreements are generally made between bordering countries regarding goods transit. However, the desire to work in a workplace established in the border region of the neighbouring country, coming from the economically weaker country, is not generally met with sympathy. In other words, for the development of goods and trade, it is not possible for the citizens of both sides to visit the other side by agreement, even for limited areas, and for the workforce of the economically weaker country to cross over to the other side and find the opportunity to work there.

Essentially, while making evaluations about the sovereignty of each state; The fact that the domestic workforce is following a policy of protection is of the most encountered problems in practice. In this case, the neighbouring country, which is economically stronger, is not very willing

\footnotetext{
${ }^{2}$ This information relates to the benefits of free trade and investment in general, but also to trade in border areas in particular (KARADUMAN, Naci/YILDIZ, Zafer: "Serbest Bölge Uygulamalarının Dış Ticarete ve Yabancı Sermayaye Katkıları”, Süleyman Demirel Üniversitesi İktisadi ve İdari Bilimler Fakültesi Dergisi, 7(1), 2002, p.136-137).

${ }^{3}$ OECD, 2018, "Trade Facilitation and the Global Economy", OECD Publishing, Paris, Word Bank,

https://www.oecd.org/publications/trade-facilitation-and-the-global-economy-9789264277571-en.htm, (Date of Access: 24.04.2021)

${ }^{4}$ FERRO, p.8.
} 
to accept new workers, which will reduce its labour market. Problems start after this point. In general, a legal passport and other legal actions (visa, etc.) are required for workers who come to work. Even after the worker's arrival, in general, the legal right to work without a work permit is not recognized. On the other hand, apart from all kinds of legal permissions of the worker who came to a more prosperous country; There is no social security Premium or tax liability. All these require additional effort. It can even be said that the employment of such workers is tied to much more limited and much stricter conditions than a normal domestic worker.

\section{III.BORDER WORKERS STANDARDS ACCORDING TO ILO}

\section{A. General Labour Standards According to ILO}

Workers of neighbouring countries may have the opportunity to work in the neighbouring country. The opportunity is closely related to the economic situation of the neighbouring country. In other words, workers of the country with lower economic power will naturally have more opportunities to work in the country with more economic opportunities.

This is obviously a great advantage at first sight. However, employers may also take advantage of the workers of neighbouring countries, by offering them lower labour standards or lower wage. If they are to work with the same labour standards and with the same wage, employers then would prefer their own citizens. In this regard, ILO states that the following issues should be taken seriously.

It is known that global and regional labour forces positively affect cross-border recruitment. Those forces include demographic and economic inequalities, advancements in communications, transportation, and labour rights. We see that trend in European countries. Of course, like Austria, the high wage levels in the neighbouring country make it an attractive labour market for labour residing in neighbouring states 5 .

Unfortunately, foreign workers continue to do primarily "blue collar" jobs, and many of them require a lot of effort. They work in jobs that require more physical strength. In particular, there is a high proportion of foreign workers with lower incomes in neighboring countries.

Sectors of the economy affected by the crisis. As mentioned earlier, the dominant part the foreign workforce is still employed in the processing trade. It is undisputed that it is also reflected in the wage levels of the labor force ${ }^{6}$.

It is necessary to understand the current structure of the labour market. There are several actors involved in regulating the market that have so far gone unnoticed. Given the growing presence of mobile workers, most studies focus on the supply side, their motivation and expectations, their skills, their use of social networks, or how they form their identity. The aim of this study is to shed light on the role of bordering country citizens in employment in border countries.

Different labour mobility patterns between regions have led to significant changes in employment structures. From a sociological perspective, the consequences on the local labour market are particularly important in terms of social inequality. Mobility can negatively impact workforce arrangements, dividing workers along national, ethnic, linguistic, and cultural lines?

\section{B. Non-Discrimination Between Local and Foreign Workers}

The principle of "equal treatment" and "non-discrimination" among people has many dimensions. Domestic, foreign, male, female, white and black. The discrimination and distinction between race and different ethnicities, between citizens and non-citizens, as well as distinctions such as poor and rich, are classifications that are not generally accepted by legal systems. This prohibition is an issue that is included in many international conventions. On the other hand, the principle of non-discrimination between domestic and foreign workers is also included in the following international conventions. At this point, the main factor is whether the workers working in another country enter that country legally. If the worker, who is a citizen of a foreign border country, lives in the more prosperous country (or in the border region) and also has the right to work, the right to equality can be claimed much more strongly. From now on, there will be no difference in terms of labour rights, social security rights, employer's observance of workers,

\footnotetext{
${ }^{5}$ WIESBÖCK, Laura: "A preferred workforce? Employment practices of East-West cross-border labour commuters in the Central European Region”, https://link.springer.com/article/10.1007/s11614-016-0245-3, (Date of Access: 22.04.2021).

6 ILO, https://www.ilo.org/wcmsp5/groups/public/---ed_protect/---protrav/---migrant/documents/publication/wcms 201039.pdf, (Date of Access: 22.05.2021).

${ }^{7}$ WIESBÖCK, p.21.
} 
workers' occupational health and safety rights, obtaining workers' receivables, and when necessary, asserting and defending their rights before legal authorities. It shouldn't be. These are the international conventions and rules we have mentioned; warns both the employer and the relevant state authorities not to make any distinctions ${ }^{8}$.

These scientific theories are derived from the "Universal Declaration of Human Rights" that it basically rejected the violation of equality (Article 2). On the other hand, it is a fundamental principle that is present in all international conventions and western constitutions adopted immediately in relation to the university ${ }^{9}$. In this regard, it is possible to say that there is an agreement on the functioning of the European Union with the revised European Social Charter (the agreement that replaces the basic agreement establishing the European community), article $10^{10}$. Apart from these international fundamental treaties, we must specify the International Covenant on Economic, Social and Cultural Rights adopted by the United Nations ${ }^{11}$. As it has been explained in article 3 "The States Parties to the present Covenant undertake to ensure the equal right of men and women to the enjoyment of all economic, social and cultural rights set forth in the present Covenant." The prohibition of discrimination in this main text also covers domestic workers and workers from neighbouring countries.

Within the framework of the general principles of the ILO, a person who has the right to work in any bordering country and citizen of other side country living in worse conditions; discrimination and discrimination among employees will constitute a violation of universal labour law principles.

ILO standards on equality provide facilities to eliminate discrimination in all parts of work and in society in general. It refers to the principle of equality in all conventions and recommendations of the ILO. These two contracts are the most basic contracts in this regard: C100 - Equal Remuneration Convention, 1951 (No. 100) and Discrimination (Employment and Occupation) Convention, 1958 (No. 111).

When talking about inequality and discrimination, treating a person worse than another person in the same position and especially in working relations; it is used in the sense of making a distinction between locals and foreigners among those doing the same job, but they have different facilities and salaries ${ }^{12}$.

Even if the reasons such as a different ethnicity, nationality or religion are not directly cited as the justification for the discrimination applied, it would be contrary to the "discrimination or equal treatment debt". Undoubtedly, employers' application of different wages to workers who work in different situations without such discrimination, at their own working discretion, will not be contrary to equal treatment debt.

If a threatening, hostile, or humiliating environment is created among border workers in the employer's practice, despite the fact that they have the right to work, it will be accepted that it is "contrary to the employer's obligation to treat them equally" and the existence of discrimination claims will be accepted ${ }^{13}$.

The new job opportunities provided by the border trade and the new job opportunities that arise with the use of opportunities are very beneficial for the employees. There does not appear to be any discussion on this issue. However, possible and probable domestic-foreign (citizen of neighbouring country) distinctions among employees may cause major problems in the long run, if not in the short run ${ }^{14}$.

According to article 10 of the Constitution of Turkey, which is entitled as "equality before the law", states that everyone is equal before the law without distinction as to language, race, colour,

${ }^{8}$ SÜZEK, Sarper: İş Hukuku (Labour Law), $17^{\text {th }}$ Ed., İstanbul 2019, p.396.

9 DANKA, Victor/FLINTERMAN, Cees/LECKIE, Scott: "Commentary to the Maastricht Guidelines on Violations of Economic, Social and Cultural Rights Report”, Human Rights Quarterly, (20), 1998, (Date of Access: 04.05.2021), p.5.

${ }^{10}$ MOLLAMAHMUTOĞLU, Hamdi/ASTARLI, Muhittin/BAYSAL, Ulaş: İş Hukuku Ders Kitabı, C.1, Gözden Geçirilmiş 3. Baskı, LYKEION Yayınları, Ankara 2019, p.26.

11 TUNCAY, Aziz Can: İş Hukukunda Eşit Davranma İlkesi, İstanbul 1982, p.150; MOLLAMAHMUTOĞLU/ ASTARLI/BAYSAL, p.194.

${ }^{12}$ ILO, https://www.ilo.org/global/standards/subjects-covered-by-international-labour-standards/equality-ofopportunity-and-treatment/lang--en/index.htm, (Date of Access: 11.05.2021)

${ }^{13}$ EKMEKÇI, Ömer/KORKUSUZ, M. Refik/UĞUR, Ömer: Turkish Individual Labour Law, On İki Levha Publishing, Istanbul 2020, p.73.

${ }^{14}$ ÇELİK, Nuri/CANIKLIOĞLU, Nurşen/CANBOLAT, Talat: İş Hukuku Dersleri (Labour Law Courses), $31^{\text {st }}$ Ed., Istanbul 2018, p.401; EKMEKÇİ/KORKUSUZ/UĞUR, p.74. 
sex, political opinion, philosophical belief, religion and sect, or any such grounds. Although there is no explicit provision on equal treatment in general, it is accepted that the said article of the Constitution regulates not only prohibition of discrimination but also the principle of equal treatment ${ }^{15}$.

In consequence of the principle of equal treatment, it is expecting from employers to treat equally to between employees who are working at the same workplace, working at the same time period and subject to a collective implementation. Employers cannot treat all of their employees (specially between citizen workers and foreign workers) in complete equality. Duty of equal treatment applies to the citizens and foreign employees who are working under the same or similar conditions. Hence, employers may implement different working conditions to different employees due to the fact that there are objective reasons ${ }^{16}$.

\section{Other Rights of Foreign Workers According to ILO Standards}

In addition to the above-mentioned "equal treatment" and "non-discrimination" obligation, workers who are citizens of the neighbouring and bordering state holding the title of foreign worker also have the following rights of workers legally working in the country. The points that should not be differentiated in any way between domestic and foreign workers can be determined as follows: Duty of care, protection of personality, protection against abuses, protection of personal data, occupational health and safety and social security rights.

\section{Duty of Care}

Employer's duty of care is the reflection of employee's duty of loyalty. Since the employment contract establishes a personal relationship between the parties, the employer shall protect and supervise the employees while employees behave for the benefit of the employer and to avoid behaviours that would harm him/her ${ }^{17}$.

\section{Protection of Personality}

The provision that directly aims to protect the personality of employees takes place under the Article 417 of TCO. Accordingly, in an employment relationship, the employer shall protect and respect the personality of the employee and organize the workplace in accordance with the principle of good faith; and especially take necessary measures to prevent employees to face psychological and sexual abuses and to get more damage if one is faced such abuses. So that, the employee will have a comfortable and peaceful environment to work.

\section{Protection Against Abuses}

Abuse is defined in the international labour standards as any act of intimidation, degrading, humiliating or embarrassing behaviour that is intended to violate human dignity or give rise to such a result including psychological and sexual types. The source of psychological or sexual abuse is not important. It may be the employer, other employees, or someone outside of the workplace. In any case, the employer is under the duty to prevent the abuse or to prevent the employee to get more damage if the abuse has already been occurred.

\section{Protection of Personal Data}

Protection of the personal data of the employees is also one of the aims of the employer's duty to care. Personal data of an employee is considered as a part of the right of privacy. Privacy of private life is regulated under the article 20 of the Constitution of Turkey, addition to international labour standards. Accordingly, everyone has the right to demand respect for his/her private and family life; and right to request the protection of his/her personal data. This right includes being informed of, having access to and requesting the correction and deletion of his/her personal data, and to be informed whether these are used in consistency with envisaged objectives. Personal data can be processed only in cases envisaged by law or by the person's explicit consent.

\section{Occupational Health and Safety}

The employer shall take all necessary precautions to ensure the occupational health and safety in the workplace and provide tools and materials completely (Art. 417/2 of TCO). Duties of employers regarding the occupational health and safety may be listed as follows:

\footnotetext{
${ }^{15}$ EKMEKÇİ/KORKUSUZ/UĞUR, p.74; SÜZEK, p.451; ÇELIK/CANIKLİOĞLU/CANBOLAT, p.401; EKMEKÇİ, Ömer/YİĞİT, Esra: Bireysel İş Hukuku Dersleri (Individual Labour Law Courses), On İki Levha, İstanbul, 2020, p.276.

${ }^{16}$ SÜZEK, p.453-454; ÇELİ/CANIKLIOĞLU/CANBOLAT, p.403; SENYEN-KAPLAN, Emine Tuncay: Bireysel İş Hukuku (Individual Labour Law) $9^{\text {th }}$ Ed., Gazi Kitabevi, Ankara 2018, p.237. ${ }^{17}$ SÜZEK, p.399.
} 
- Duty to monitor and supervise.

- Duty to train and inform.

- Duty to perform risk assessment.

- Duty to perform healthcare surveillance.

- Duty to report work accident and to keep record.

- Duty to prepare emergency plan and to evacuate.

- Duty to establish committee of occupational health and safety.

Duty to employ occupational health and safety professionals ${ }^{18}$.

\section{Social Security Rights}

Apart from the labour rights, workers have social security rights to be protected too. The main problem about the social security rights of the workers working in the border zones of neighboring countries is that their social security premiums are paid to another country's social security system. Therefore, they may face problems when they want these premiums to be taken into account in their home countries. There are indeed some solutions to overcome these problems. One of these solutions is to have social security agreements between the neighboring countries. Contracting states may regulate the situation of these workers ${ }^{19}$. It is seen in the numerous social security agreements that the works conducted in the other contracting party are regarded as the works conducted in the home country. By this way, workers can fulfill the requirements to receive social security benefits. Another solution can be allowing workers to pay the premiums to the social security institution of the home country for the periods where the worker conducted his/her works in foreign countries. As a result of this payment, the social security institution of the home country can take these works conducted in a foreign country as they were conducted in the home country ${ }^{20}$. Lastly, countries should allow workers working in the border zones of neighboring countries to join voluntary social insurance. So that they can pay their premiums by themselves and fullfil the requirements of receiving social security benefits. Besides all these, workers must have the opportunity to transfer the social security premiums paid in the neighboring country to their home country. They may overcome the problem of paying double premiums in two different countries for the same period of time with the transfer of the premiums. However, this can only be possible if two countries have an agreement on this transaction.

\section{CONCLUSION AND ASSESMENT}

As a result of the increase in border trade in the world, it is indisputable that there are additional employment opportunities, especially for citizens of more developed countries.

It is obvious that border trade, which is a good advantage in providing jobs and employment, leads to the employment of a large number of people due to goods transportation, hotels, restaurants, storage centres and customs enterprises.

But it is a fact that employees of countries who are more disadvantaged receive different treatment in the employment in developed countries. International conventions, which prohibit all kinds of discrimination, as well as discrimination between domestic and foreign workers, constitute the clearest international sources on this subject. In order to eliminate this bad treatment, the employment strategies identified by the ILO should be taken into consideration and discrimination between employees should be removed. Even if the reasons such as a different local or foreign, ethnicity or religion are not directly cited as the justification for the discrimination applied, it would be contrary to the discrimination or equal treatment debt for the employers. Other points that should not be differentiated in any way between domestic and foreign workers can be determined as follows: Duty of care, protection of personality, protection against abuses, protection of personal data, occupational health and safety.

Apart from the rights of the workers regarding the individual labour law, their social security rights have to be protected too. As it was mentioned with more details above, the necessary measures has to be taken to allow these workers to meet the requirements of receiving the social securty benefits. This can be achieved by entering into a social securty agreement with neighboring countries or by allowing them to accumulate social security premiums in their home countries

\footnotetext{
${ }^{18}$ EKMEKÇİ/KORKUSUZ/UĞUR, p.77-78; SÜZEK, p.400.

${ }^{19}$ GÜZEL, Ali/OKUR, Ali Rıza/CANIKLİOĞLU, Nurşen: Sosyal Güvenlik Hukuku (Social Security Law), Beta, İstanbul, 2020, p.46

${ }^{20}$ GÜZEL/OKUR/CANIKLİĞLU, p.539; TUNCAY, A. Can/EKMEKÇİ, Ömer: Sosyal Güvenlik Hukuku Dersleri (Social Security Law Courses), Beta, İstanbul, 2019, p.722.
} 
during their work in the border zones of the neighboring countries. These methods can be combined too. Transfer of the premiums between these countries is also another important issue to protect the rights of these workers.

Within the framework of the general principles of the ILO and other international agreements, a person, who has the right to work in any bordering country and who is a citizen of a poorer country and living in worse conditions, deserves to be treated as an honourable worker. There should also be more international materials on the protection of the rights of the workers working in the border zones of the neighboring countries.

\section{REFERENCES}

ÇELIK, Nuri/CANIKLIOĞLU, Nurşen/CANBOLAT, Talat: İş Hukuku Dersleri (Labour Law Courses), 31st Ed., Istanbul, 2018.

DANKA, Victor/FLINTERMAN, Cees/LECKIE, Scott: "Commentary to the Maastricht Guidelines on Violations of Economic, Social and Cultural Rights Report", Human Rights Quarterly, (20), 1998, (Date of Access: 04.05.2021)

EKMEKÇİ, Ömer/KORKUSUZ, M. Refik/UĞUR, Ömer: Turkish Individual Labour Law, On İki Levha Publishing, Istanbul, 2020.

EKMEKÇİ, Ömer/YİĞIT, Esra: Bireysel İş Hukuku Dersleri (Individual Labour Law Courses), On İki Levha, İstanbul, 2020.

FERRO, Cécile et al.: "Trading Across Borders: A New Approach to Measuring Trade Processes Across Borders", https://www.doingbusiness.org/content/dam/doingBusiness/media/AnnualReports/English/DB16-Chapters/DB16-CS-TAB.pdf, (Date of Access: 05.05.2021)

GÜZEL, Ali/OKUR, Ali Rıza/CANIKLİOĞLU, Nurşen: Sosyal Güvenlik Hukuku (Social Security Law), Beta, İstanbul, 2020.

ILO, https://www.ilo.org/global/standards/subjects-covered-by-international-labour-standards/equality-ofopportunity-and-treatment/lang--en/index.htm, (Date of Access: 11.05.2021)

ILO, https://www.ilo.org/wcmsp5/groups/public/---ed_protect/---protrav/migrant/documents/publication/ wcms_201039.pdf, (Date of Access: 22.05.2021).

KARADUMAN, Naci/ YILDIZ, Zafer: "Serbest Bölge Uygulamalarının Dış Ticarete ve Yabancı Sermayaye Katkıları”, Süleyman Demirel Üniversitesi İktisadi ve İdari Bilimler Fakültesi Dergisi, $7(1), 2002$.

MOLLAMAHMUTOĞLU, Hamdi/ASTARLI, Muhittin/BAYSAL, Ulaş: İş Hukuku Ders Kitabı, C.1, Gözden Geçirilmiş 3. Baskı, LYKEION Yayınları, Ankara, 2019.

OECD, 2018, "Trade Facilitation and the Global Economy", OECD Publishing, Paris, Word Bank, https://www.oecd.org/publications/trade-facilitation-and-the-global-economy9789264277571-en.htm, (Date of Access: 24.04.2021).

SENYEN-KAPLAN, Emine Tuncay: Bireysel İș Hukuku (Individual Labour Law) 9th Ed., Gazi Kitabevi, Ankara, 2018.

SÜZEK, Sarper: İş Hukuku (Labour Law), 17th Ed., İstanbul, 2019.

TUNCAY, Aziz Can: İş Hukukunda Eşit Davranma İlkesi, İstanbul, 1982.

TUNCAY, A. Can/EKMEKÇİ, Ömer: Sosyal Güvenlik Hukuku Dersleri (Social Security Law Courses), Beta, İstanbul, 2019.

WIESBÖCK, Laura: "A preferred workforce? Employment practices of East-West cross-border labour commuters in the Central European Region", https://link.springer.com/article/10.1007/s11614-016-0245-3, (Date of Access: 22.04.2021). 